\title{
THE NATURE OF THE INFERIOR OVARY IN SOME MONOCOTYLEDONOUS FAMILIES
}

\author{
$\underline{\text { Sherif Mohamed SHARAWY }}^{1^{*}}$, Sayed Farag KHALIFA ${ }^{1}$ \\ ${ }^{1}$ Botany Department, Faculty of Science, Ain Shams University, Abbassya 11566, Cairo - Egypt \\ * Corresponding author. E-mail: sherifsharaawy@yahoo.com
}

\begin{abstract}
The floral vasculature aspects of twenty-four species belonging to six monocotyledonous families are dealt with. These selected taxa include 23 horticulture species cultivated in Egypt and the remainders is among the wild flora of Egypt. A great attention has been focused by phylogenetists on the position of the ovary with respect to the other parts of the flower. In this connection, the nature of the inferior ovary is generally discussed on the basis of two theories; appendicular and axial. It is fortunate that the vascular skeleton can still be regarded as the most conservative character and that it may be rather conclusive in the determination of the nature of the inferior ovary. In the present study, the different patterns of floral vascularization are presented in cumulative tables and figures to facilitate the comparative study. Moreover, an interpretation to the observed variations is also tried to reach at the relations between the taxa studied and to determine the nature of the hypanthium.
\end{abstract}

Keywords: Epigynous flower, floral vasculature, hypanthium, inferior ovary, monocotyledons.

\section{Introduction}

More than other plant part the flower has always received a great attention on telling evolutionary pathways; and of all the floral phenomena that of the inferior ovary has doubtless been extensively discussed [DOUGLAS, 2003; BASSO-ALVES \& al. 2017]. Since the nineteenth century two theories about its nature have received strong support and simply presented, these are the appendicular theory and the axial theory.

Under the appendicular theory, also called the Candollean theory and the concrescence theory; the ovary becomes inferior by the adnation of the bases of the outer floral whorls to the gynoecium; while the axis forms no part of the ovary wall. Supporters to this theory were VAN TIEGHEM (1871), DE CANDOLLE (1891), SWAMY (1948), BLASER (1954), DOUGLAS (1957), STEBBINS (1977), KHALIFA \& al. (2009). Under the axial theory, also called the receptacular theory, the inferior ovary is considered to consist of tissues of the axis that form an invaginated floral receptacle surrounding the gynoecium and adnate to it. Among the holders of this theory were PAYER (1857), DOUGLAS (1957) and EAMES (1974).

Not easy as above either theory can be accepted since the whole situation is further complicated by the so-called hypanthium. This hypanthium is an expression of the tendency for the floral parts of different kinds to fuse together to form one morphological entity which often resembles the calyx in texture thus giving an impression of a calyx tube [GUSTALSSON \& ALBERT, 1999]. The degree of fusion of petals (or inner perianth) and the stamens to this tube as well as their leveling is so diverse that many versions of epigyny do exist, and thus causing controversy about the nature of the inferior ovary whether totally axial, totally appendicular or partially this or that. More difficulty is confronted for the 
hypanthium, although appearing as a simple morphological structure, yet it is actually compound anatomically.

In spite of this, many cases in the dicots have been correctly comprehended and the nature of the inferior ovary has been satisfactorily assigned. In monocots, however the case is not as easy as in dicots. This is because as STEBBINS (1977), states, epigyny in monocots is derived by routes which differ from those of the dicots. However, he directed the attention towards the following points: 1- In most monocotyledonous hypogenous flowers the rule is the undifferentiating of the perianth into sepals and petals. If any differentiation occurs, it will be so weak. That the intercalary concrescence between the members produces a floral tube ending into a single series of free perianth lobes. 2 - In some genera the stamen filaments are adnate to the perianth tube and the structure is somewhat, but not completely, analogous to the hypanthium of the Rosales. 3- The epigynous flowers in most of the Amaryllidaceae are probably derived from such perigynous flowers but the direct origin of epigyny from hypogyny, at least in monocots is certainly a possibility. 4The determination of the nature of the inferior ovary represents a remarkable controversy if one has to decide whether it is axial, appendicular or both. The latter case originates through the adnation of the floral parts on one hand and the concavity of the receptacle makes at least a part of the ovary wall to be axial [PURI, 1951; KAPLAN, 1967; CRONQUIST, 1968].

Again and over a century the problem of the nature of the inferior ovary received its due attention. The comprehensive review by DOUGLAS (1944) represented a trigger for diverse interpretations and conclusions. In the same review it became clear that the internal region of the ovary wall is truly carpellary, but great controversy arose about the nature of its outer region. As regards this latter region one group of workers believed in its appendicular nature [DUCHARTRE, 1841; LESTIBOUDOIS, 1855; TREVIRANUS, 1861; KOEHNE, 1869; VAN TIEGHEM, 1870; BOUTINEAU, 1883; SAUNDERS, 1925 a,b,c; KOZO POLJANSKI, 1926; DOWDING, 1931; EAMES, 1931; EAMES \& MAC DANIELS, 1947; OKIMOTO, 1948; SWAMY, 1948; BLASER \& EINEST, 1950; ROSTOGI, 1951; KHALIFA \& al. 2009]. The second group of workers considered it to be receptacular [DUCHARTRE, 1842; TREVIRANUS, 1859; HENSLOW, 1891; KIRKWOOD, 1905; JUDSON, 1929; SMITH \& SMITH, 1942; SHARMA, 1949]. As a compromise, EAMES (1974) stated that the inferior ovary had developed in two morphologically different ways by adnation of the floral appendages and by hollowing the axis tip.

The interpretation of the nature of inferior ovary is not easy to explain when the force of connation has resulted in some events as syncarpy, and when the adnation produces unions of floral parts, delimitation of the receptacular tissue is mostly impossible and interpretation of the basic flower structure in syncarpous ovaries would differ widely. Thus, the validity of using the anatomical method in determining the nature of inferior ovary becomes of vital significance. It is fortunate that the vascular skeleton can still be regarded as the most conservative character and that it may be rather conclusive in the determination of the nature of the inferior ovary. Moreover, an interpretation to the observed variations is also tried to reach at the relations between the taxa studied and to determine the nature of the hypanthium. 


\section{Material and methods}

Twenty-four species belonging to six monocotyledons families are dealt with. These taxa include 23 horticulture species cultivated in Egypt and the remainder is among the wild flora of Egypt. All taxa were identified after TÄCKHOLM (1974), BAILEY (1976), HUXLEY \& al. (1992) and BOULOS (2000 \& 2009). Herbarium specimens were kept at the Botany Department Herbarium, Faculty of Science, Ain Shams University. The families and the taxa studied are cited in Table 1 and arranged according to APG II (2003). The different localities of the taxa studied are also cited in Table 1. The flower buds of the studied taxa were fixed and preserved in F.A.A. embedded in paraffin wax, then serially sectioned at $10-15 \mu$ according to conventional method [JOHANSEN, 1940]. Sections stained in crystals violet-erythrosine (saturated in clove oil) combination. Some photos were presented to clarify critical cases.

Table 1. The different localities of the studied taxa [the taxa are arranged according to APG II (2003)]

\begin{tabular}{|c|c|c|c|}
\hline Family & Genus & Species & Locality \\
\hline \multirow{9}{*}{ Amaryllidaceae } & Agave & $\begin{array}{l}\text { A. americana } \mathrm{L} \text {. } \\
\text { A. lophantha Schiede ex Kunth. } \\
\text { A. sisalana Perrine }\end{array}$ & $\begin{array}{l}\text { OBG } \\
\text { OBG } \\
\text { OBG }\end{array}$ \\
\hline & Clivia & C. miniata (Lindl.) Bosse & ZBG \\
\hline & Crinum & $\begin{array}{l}\text { C. augustum Roxb. } \\
\text { C. bulbispermum (Burm.f.) Milne-Redh. \& } \\
\text { Schweick. } \\
\text { C. x powellii Baker }\end{array}$ & $\begin{array}{l}\text { ZBG } \\
\text { BGA } \\
\text { BGA }\end{array}$ \\
\hline & Curculigo & $\begin{array}{l}\text { C. capitulata Kuntze. } \\
=\text { Molineria capitulata (Lour.) Herb. }\end{array}$ & OBG \\
\hline & Furcraea & F. foetida (L.) Haw. & OBG \\
\hline & Hippeastrum & H. vittatum (L'Hér.) Herb. & BGA \\
\hline & Hymenocallis & H. caribaea (L.) Herb. & OBG \\
\hline & Narcissus & N. tazetta L. & OBG \\
\hline & Pancratium & P. maritimum L. & Mma. \\
\hline Bromeliaceae & Billbergia & $\begin{array}{l}\text { B. nutans } \mathrm{H} \text {. Wendl. ex Regel } \\
\text { B. x windii Baker }\end{array}$ & $\begin{array}{l}\text { BGA } \\
\text { BGA }\end{array}$ \\
\hline Cannaceae & Canna & C. indica $\mathrm{L}$. & BGA \\
\hline \multirow{4}{*}{ Iridaceae } & Antholyza & A. aethiopica $\mathrm{L}$. & $\mathrm{ABG}$ \\
\hline & Freesia & F. refracta (Jacq.) Klatt & BGA \\
\hline & Gladiolus & G. x gandavensis Van Houtte & BGA \\
\hline & Iris & I. $\mathrm{x}$ germanica $\mathrm{L}$. & BGA \\
\hline \multirow{2}{*}{ Musaceae } & Musa & M. nana Lour. & BGA \\
\hline & Strelitzia & S. reginae Banks & OBG \\
\hline \multirow[t]{2}{*}{ Zingiberiaceae } & Alpinia & $\begin{array}{l}\text { A. speciosa Schum. } \\
=\text { Etlingera elatior (Jack) R. M. Sm. }\end{array}$ & OBG \\
\hline & Hedychium & H. coronarium J. Koenig & OBG \\
\hline
\end{tabular}




\section{Results and discussions}

The results obtained in this study are concerned the different patterns of floral vascularization and their discussion is subsequently presented.

I. The pedicel vasculatures (Table 2)

Within the studied taxa the pedicel vasculature ranges between the numerous, scattered vascular bundles (14 taxa) (Figure $1 \mathrm{a}$ ) or in the form of number of vascular bundles definitely arranged. These are either 6 bundles in Clivia miniata and Narcissus tazetta (Figure $1 \mathrm{~b}$ ); or the supply is formed of outer 6 bundles and one inner vascular mass in Antholza aethiopica, or outer 12 bundles and 6 inner vascular masses in Crinum x powellii; or outer 16 bundles and inner 7 vascular masses in Hedychium coronarium (Figure $1 \mathrm{c}$ ) or 9 vascular masses forming a ring in Alpinia speciosa; or a central hexagonal stele in Freesia refracta and Gladiolus gandavensis (Figure $1 \mathrm{~d}$ ). In the remaining two taxa Curculigo capitulate and Crinum bulbispermum the pedicel vasculature is in the form of numerous vascular bundles arranged in a ring (Figure $1 \mathrm{e}$ ).

\section{The perianth leaves vasculatures (Table 2)}

\section{A. The outer perianth leaves vasculatures}

\section{Outer median tepal bundle}

The origin of these bundles is either independent in 17 taxa (Figure 1 a) or dependent in the remaining taxa. It could then be mentioned that the dependent state is either resulting from the incorporation of such bundles with outer staminal traces (Agave americans, Anotholyza aethiopica and Gladiolous x gandavensis) (Figure 2 e) or from the incorporation of such bundles with both the outer staminal traces and the carpellary dorsal bundles (Hymenocallis caribaea, Narcissus tazetta, Billbergig nutans and Iris x germanica) (Figure 2 d). The initial number and the final number of the outer median tepal bundles is one for each tepal in all the taxa under investigation.

\section{The outer marginal tepal bundles}

The origin of the outer marginal tepal bundles in the taxa studied is either independent in 12 taxa (Figure 1a) or dependent in the other 12 taxa. The dependent case is resulting from the incorporation of such bundles with the other bundles. Thus, the following forms are observed: with outer staminal strands in Clivia miniata, with outer staminal and carpellary dorsal strands in Crinum x powellii and Hippeastrum vittatum, with inner median and marginal tepal strands in the all studied taxa of the family Iridaceae (Figure 2 e \& f) and with inner marginal and outer marginal tepal strands in Crinum bulbispermum, Curculigo capitulata, Narcissus tazetta, Pancratium maritimum and Billbergia nutans (Figure $2 \mathrm{~d}$ ). The initial number of the outer marginal traces varies. It is either two traces in seven taxa (Figure $2 \mathrm{c}$ ), six traces in eight taxa, 25 traces in Crinum x powellii, nine traces in Crinum bulbispermum or numerous traces in seven taxa. Generally, in the taxa studied there are numerous outer marginal bundles (Figure 5 a) except in Clivia miniata where there are only six bundles.

\section{The outer androperianth strands}

Generally, absent in 15 of the 24 taxa studied. However, the results obtained indicated the presence of such strands in the remaining nine taxa (Table 2). The level of differentiation and separation of these strands to their components is different. Thus, the following types are presented: separation at the base of the ovary in Agave americana, Hymenocallis caribaea and Billbergia mutans, separation at the middle of the ovary in Crinum x powellii, separation at the top of the ovary in Hippeastrum vittatum, Antholyza aethiopica, Gladiolus x gandavensis and Iris $\mathrm{x}$ germanica (Figure $3 \mathrm{~b}$ ), and separation at the top of the very long collar "Androperianth tube" in Narcissus tazetta (Figure $4 \mathrm{~d}, \mathrm{e}$ ). 


\section{B. The inner perianth leaves vasculatures}

The characteristic features of the vasculature of the inner perianth leaves (median, marginal and androperianth strands) of the different taxa under investigation have been indicated and presented in cumulative and comparative patterns (Table 2).

III. Floral cup (Table 2)

\section{A. Casing}

Consequently, it could be said that the nature of casing in the present work is represented in the following three types:

1. The casing is totally appendicular in the three studied taxa of Agave species, Crinum augustum, Curculigo capitulata and Furcraea foetida (Figure 2 a, b, c).

2. The casing is nearly receptacular in Narcissus tazetta (Figure $2 \mathrm{~d}$ ).

3. The casing is receptacular and appendicular in the remaining 17 taxa (Figure $2 \mathrm{e}, \mathrm{f}$ ).

\section{B. Collar}

The collar is present in most of the studied taxa (21 taxa). In the remaining studied taxa, the collar is totally absent (Crinum x powellii, Canna indica and Musa nana). The nature of the collar if present is appendicular in all of the taxa studied except Narcissus tazetta (Figure $4 \mathrm{a}-\mathrm{e})$. The extension of the collar above the ovary level is either short in 11 taxa, medium in Clivia miniata and Strelitzia reginae, long in 5 taxa, or very long in Crinum bulbispermum, Narcissus tazetta and Pancratium maritimum.

\section{Androecium vasculatures (Table 3)}

In all the taxa studied of Amaryllidaceae and Bromeliaceae, the number of fertile stamen is six in two whorls. In Iridaceae it is only three fertile stamens whereas in Canna indica (Cannaceae) it is half stamen (Figure 5 e). Musaceae (Musa nana and Strelitzia reginae) possess five stamens; three outer and two inner and in Zingiberaceae (Alpinia speciosa and Hedychium coronarium) it is only one fertile stamen (Figure $5 \mathrm{f}$ ).

The plan of androecium vasculature in all the studied taxa is composed of one trace for each stamen. These traces remain unbranched in 18 taxa (Figure $5 \mathrm{a}, \mathrm{b}, \mathrm{c}$ ). The staminal bundles are branched in both filaments and anthers forming a few bundles which trespass and enter into the anther in 5 taxa (Figure $5 \mathrm{~d}$, e, f). In Gladiolus x gandavensis, the staminal supply is originated as one bundle which is then splitted into three bundles in the staminal filaments.

The androgynoecium strands is recorded only in 14 out of the 24 taxa studied. The androgynoecium strands show considerable variation with regard to their differentiation and separation levels. Thus, the following levels can be observed:

Level 1: Separation at the middle of the ovary in Crinum bulbispermum, Hymenocallis caribaea, Pancratium maritimum and Billbergia nutans.

Level 2: Separation at the top of the ovary in 10 taxa refer to Table 3 (Figure $3 \mathrm{~b}, \mathrm{c}$ ).

V. Gynoecium (Table 3)

In all the taxa studied, the gynoecium consists of three fused (syncarpous) unlobed carpels. Each carpel has three locules with many ovules in each. It has long been established that the carpel is a 3-traced organ, one dorsal and two ventral bundles [EAMES, 1953] it is believed that this 3-traced condition is the most primitive and this has been modified by both reduction and fusion [EAMES, 1929; FAHN, 1982 \& PANDEY, 1982]. In the studied taxa, the gynoecium and its vascular supply has been found to behave in the following manner:

\section{A. Ventral bundles}

Just below the detection of the locules the floral stele is differentiated showing the following types; forming numerous traces in 12 taxa (Figure 1 a), forming six traces in 3 taxa, 
forming three vascular bundles or masses in 5 taxa, forming one vascular mass in 3 taxa and undetected vasculature in Agave lophantha. The behavior of ventral bundles has been found to behave in the following manner:

Type I. Ventral bundles arising separate and numerous for each carpel

Ia. The numerous bundles originate free. At a higher level, they undergo branching in the placental tissue for feeding the ovules and the septal regions. At the upper portion of the ovary or at the base of style, the ventral bundles fade out gradually afterwards (do not extend beyond the ovular supply).

Ib. Similar to the type Ia but the ventral bundles extend beyond the ovular supply, then fade out gradually till they completely become lost at the base of the stylar tissue.

Ic. The numerous ventral supplies fuse forming three pairs (two for each carpel) then branch for feeding the ovules and the septal region. Afterward the six ventral bundles are extended for the style and reaching the stigmatic tissue.

Id. The numerous ventral bundles originate free. At a higher level they undergo branching in the placental tissue for feeding the ovules only. At the upper portion of the ovary the ventral bundles extend beyond the ovular supply then fade out gradually till they become completely lost at the base of the stylar tissue.

Type II. Ventral bundles arising separate, two for each carpel

IIa. The ventral bundles originate free. At a higher level, they undergo branching in the placental tissue for feeding the ovules and the septal regions. Then at the base of the style the bundles fade out gradually till they are completely lost in the stylar tissue. i.e. do not extend beyond the ovular supply.

IIb. The ventral bundles originate free. At a higher level, they undergo branching in the placental tissue for feeding the ovules only. Then the ventral bundles are extended for the style and reaching the stigmatic tissue.

In type I and II, if they were the case, this character would be a primitive trend according to the principles of phylogenetic considerations [BESSEY, 1915; HUTCHINSON, 1948, 1973; TAKHTAJAN, 1969; STEBBENS, 1977; STACE, 1985]. Moreover, the feeding of one carpel in this case by three or more vascular bundles ( 2 or more separate ventral and one dorsal bundles) is regarded generally as the most primitive condition.

Type III. Ventral bundles arising fused, one for each carpel

IIIa. The two fused ventral bundles are first splitted forming 6 bundles ( 2 for each carpel). At the placental tissue, they undergo branching for feeding the ovules and the septal regions, then extend beyond the ovular supply and eventually fade out till they become completely lost at the base of the stylar tissue.

IIIb. Similar to the type IIIa, but the ventral bundles extend to feed the style up to the stigmatic tissue.

Type IV. Ventral bundles arising as a vascular mass for carpels

IVa. The vascular mass is first splitted forming six bundles ( 2 for each carpel). At the placental tissue, they undergo branching for feeding the ovules and septal regions. Then at the base of the style the bundles fade out gradually till they are completely lost in the stylar tissue, i.e. do not extend beyond the ovular supply.

IVb. The vascular mass is first splitted forming six bundles ( 2 for each carpel). At the placental tissue, they undergo branching for feeding the ovules and septal regions. Then extend beyond the ovular supply then fade out gradually till they completely lost at the base of the stylar tissue.

The ventral supply continues to the top of the ovary, after supplying the ovules. This case is recorded in most of taxa under study (15 taxa) (Figure $3 \mathrm{c}$ ). In the remaining taxa, it is 
both extended beyond the ovular supply and feed the style (Agave americana, A. sisalana, Furcraea foetida and Iris x germanica) (Figure 5 b, c), or undetected (5 taxa) (Figure 3 b).

\section{B. Septal bundles}

These bundles, if detected, lie at the same radii of the ventral bundles. EAMES (1953) stated that occasional species having branching ventral bundles and branches of these bundles running towards the margin are rare. In this study, the septal are only undetected in Agave americana, A. lophantha and Musa nana (Figure $2 \mathrm{c}$ ).

\section{Dorsal carpellary bundles}

The ovarian dorsal supply consists of one dorsal carpellary bundle per carpel. In this study, all the taxa studied persist in the stylar tissue and extend for feeding the stigma (Figure 4 a-e) except in Canna indica. In general, the total number of carpels can be traced easily by counting the number of stylar bundles. The origin of the carpellary dorsal supply is either dependent (15 taxa) or independent (9 taxa). In the former case, the carpellary dorsal supply is conjoint with complex vascular cord (Table 2 and 3 ).

\section{Carpellary wall bundles}

The carpellary wall bundles are lying on either side of the dorsal carpellary bundles and adjacent to each other. The carpellary wall bundles, if present fade out at the base of the style. These bundles are recorded in 8 taxa out of 24 taxa studied (Table 3, Figure 2 b).

\section{E. Stylar supply}

EAMES (1953) mentioned that the traces of the carpel may pass as unbranched bundles to the style or the stigma, or may branch in varying degrees. The results obtained in this study, indicate various behaviour patterns of the stylar supplies. The main variations can be presented as follows: 1 - The stylar supply is formed of 3 bundles representing the extension of the dorsal carpellary bundles. This type has been recorded in most of the taxa studied (19 taxa) (Figure $4 \mathrm{a}-\mathrm{d}$ ). 2 - The stylar supply is formed of 3 dorsal bundles and extension of the carpellary ventral bundles, this type is observed in four taxa (Figure $4 \mathrm{~b}, \mathrm{c}$ ). In Canna indica the stylar supply is not detectable (Figure $4 \mathrm{e}$ ).

The results obtained in this study, indicate the presence of a number of analytic characters of limited occurrence which help in the identification of different entities. They are also called diagnostic or key characters. Among these characteristics are presence of staminal cup (Hymenocallis caribaea and Pancratium maritimum), corona (Narcissus tazetta), half fertile stamen, petaloid stamens in Canna indica (Figure 4 e), leafy styles in Iris x germanica (Figure 4 c), posterior inner staminode in Musa nana and Strelitzia reginae and labellum in Alpinia speciosa and Hedychium coronarium (Figure $4 \mathrm{f}$ ).

The nature of floral cups in longitudinal sections (Figure 6 a-h) can be determined from the way in which their vascular traces are conjoined with the vascular stele of receptacle or the pedicel. Thus, in most perigynous and epigynous flowers, these vascular traces are separated from the receptacular stele and extend through the androperianth tube. This indicates that this organ is formed as a result of fusion of the bases of sepals, petals and stamens. In other flowers the vascular stele run off and gets fused upwards till the periphery of the receptacular tissues "Hypanthium". This means that such structure hypanthium is an extension of the receptacle i.e. does not result from the adnation of floral parts. Consequently, and because of the difficulty of differentiating between the true hypanthium and the floral cup, the floral vasculature behavior should be consulted. In this respect, the main floral patterns are recorded: 1- almost all traces run fused throughout the casing and very long collar, the separation of vascular cords or strands is taking place at the top of the collar tissue. Thus, the nature of epigyny is totally receptacular 
(Figure 6 a). 2 - The vascular supply of outer whorls consisting of partial independent traces which separate from the common vascular cords (strands) at the middle or the top of the ovary. Thus, the nature of epigyny is semi-appendicular (Figure 6 b-g). 3 - The vascular supply consisting of totally independent traces which run off distinct below the level of the locules. Thus, the nature of epigyny is totally appendicular (Figure $6 \mathrm{~h}$ ).

In view of the above discussion the subsequent suggested interpretation may be presented. It is of primary importance to draw attention towards what is meant by epigyny. The phenomenon of epigyny is the reversed topographical position of the ovary relative to the other floral organs. In hypogenous flowers the shoot apex is convex and its upper most part carries the gynoecium which is superior to the other floral organs. Evolution, as phylogenetis agree implies a cessation of the apical growth of the shoot apex and the activity of the sub-apical cells to grow and form a cup-shaped receptacle. The floral organs, other than the gynoecium occupy the rim of this concave receptacle while the ovary becomes immersed to various levels with the adnation of its wall to the receptacular tissue. The inferior ovary which results in a way other than this is believed to be a false case of epigyny. If this is to be convincing, then the hypanthium, whatever its aspect does not share in this way of transformation, viz. from hypogyny to epigyny. In this study, the controversial nature of the hypanthium decided according to the following view-points:

a. The term has been applied to the whole perianth-tube, which is a result of adnation of stamens to all the perianth leaves. In this study, this is not accepted and the whole structure is better termed the "androperianth".

b. The same tube is suggested, here to be formed of two parts; a lower one capping the ovary and termed a "casing" and an upper one termed a "collar".

c. Unless the ovary becomes inferior through the concavity of the receptacle, the phenomenon is considered as "False epigyny".

d. The nature of any organ is decided according to the above considerations.

The acceptances of the above inference, the different states of epigyny as a character are the following:

\section{The true inferior flower, ovary wholly receptacular.}

The outer floral whorls (androperianth tube) have no own vascular system. It consists of dependent traces which run off fused and later become separated from the common vascular cord "strands" at the top of the collar tissue. Thus, the nature of both casing and collar is receptacular (Narcissus tazetta).

\section{The false inferior flower}

A. The ovary semi-appendicular

The outer floral whorls "androperianth tube" have own vascular system consisting of partial independent traces which separate from the common vascular cord "strands" at the middle or at the top of ovary. Thus, the nature of casing is receptacular and appendicular whereas the collar, if present is appendicular (17 taxa).

B. The ovary wholly appendicular

The outer floral whorls (androperianth tube) have their own vascular system consisting of totally independent traces which run off distinct at a level lower than that of the locules. Thus, the casing and the collar, if present are appendicular (Agave americana, A. lophantha, A. sisalana, Crinum augustum, Curculigo capitulata and Furcraea foetida). 


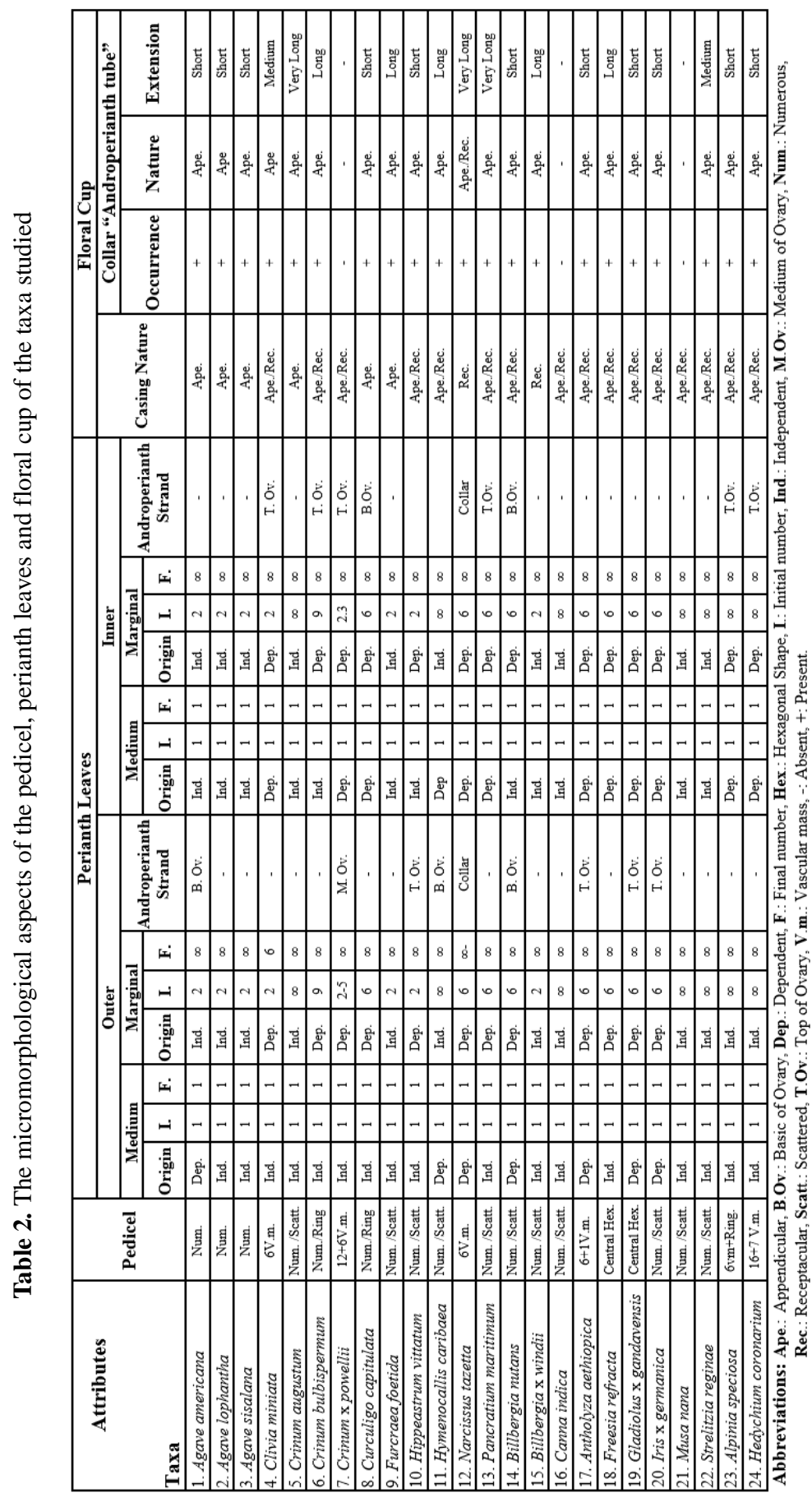




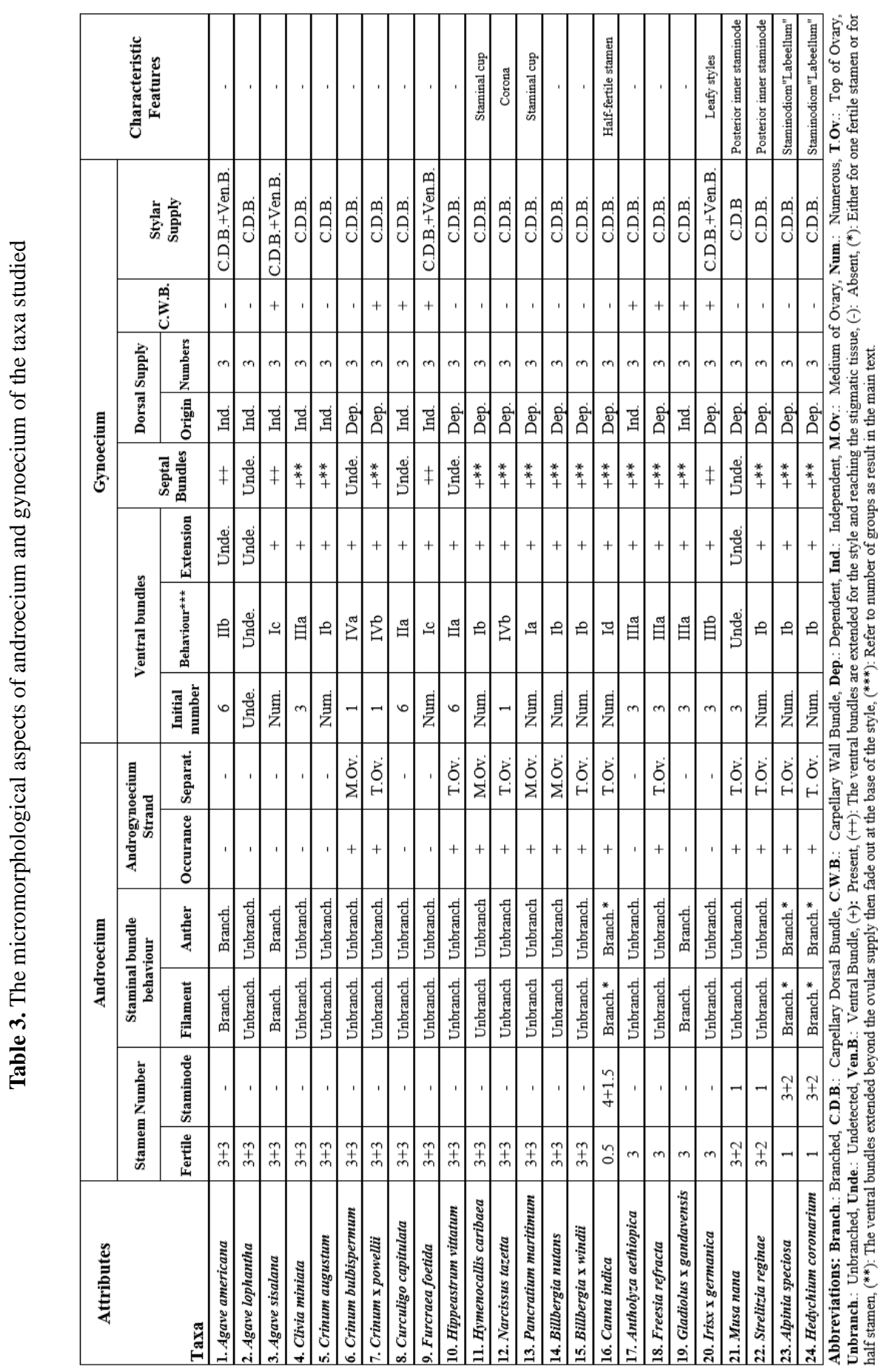



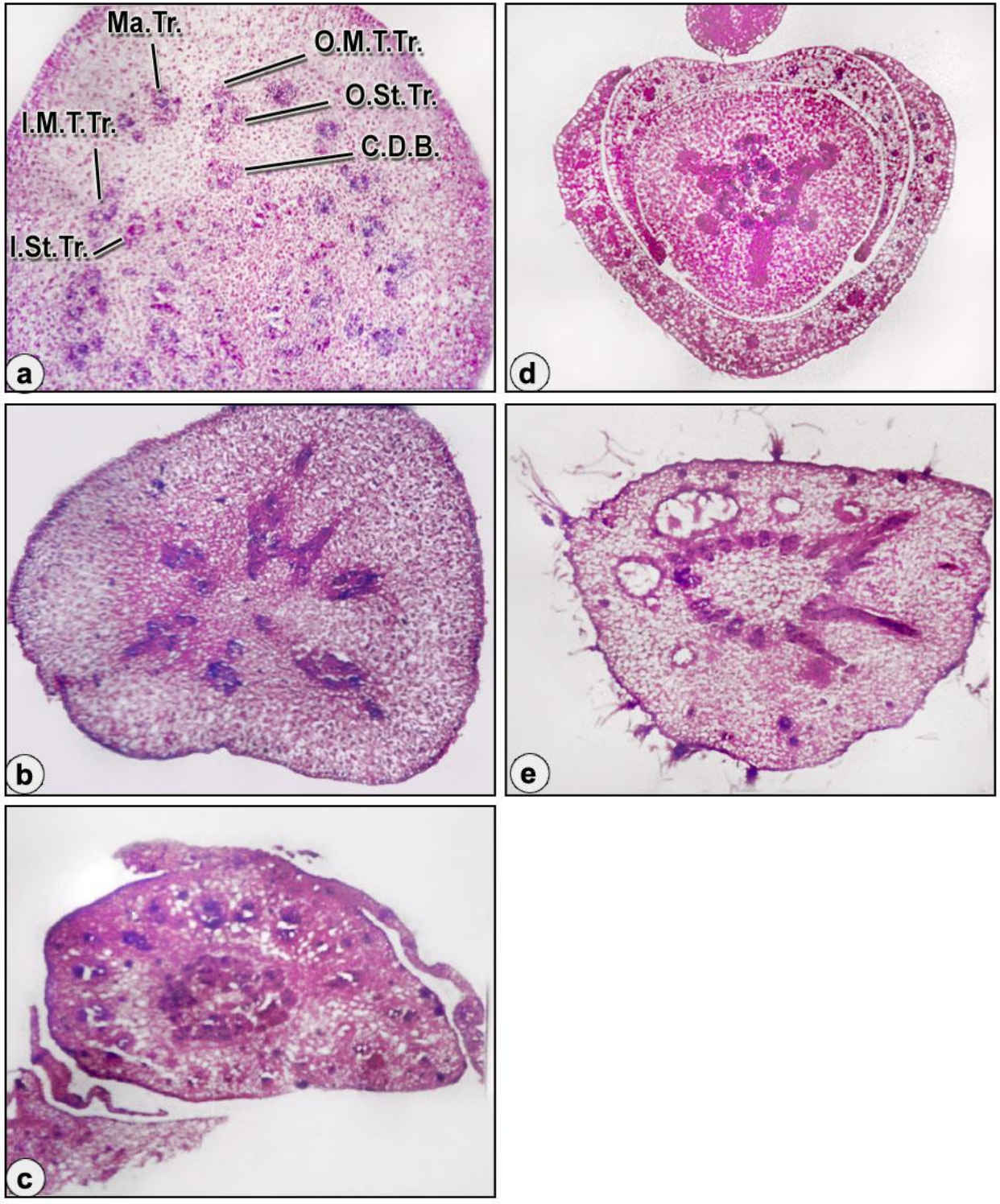

Figure 1. Variations in the pedicel vasculature in some of the taxa studied. a. Agave americana, b. Clivia miniata, c. Hedychium coronarium, d. Freesia refracta, e. Curculigo capitulata.

Abbreviations: C.D.B.: Carpellary Dorsal Bundle; I.M.T.Tr.: Inner Median Tepal Trace; I.St.Tr.: Inner Staminal Trace; Ma.Tr.: Marginal Trace; O.M.T.Tr.: Outer Median Tepal Trace; O.St.Tr.: Outer Staminal Trace. 

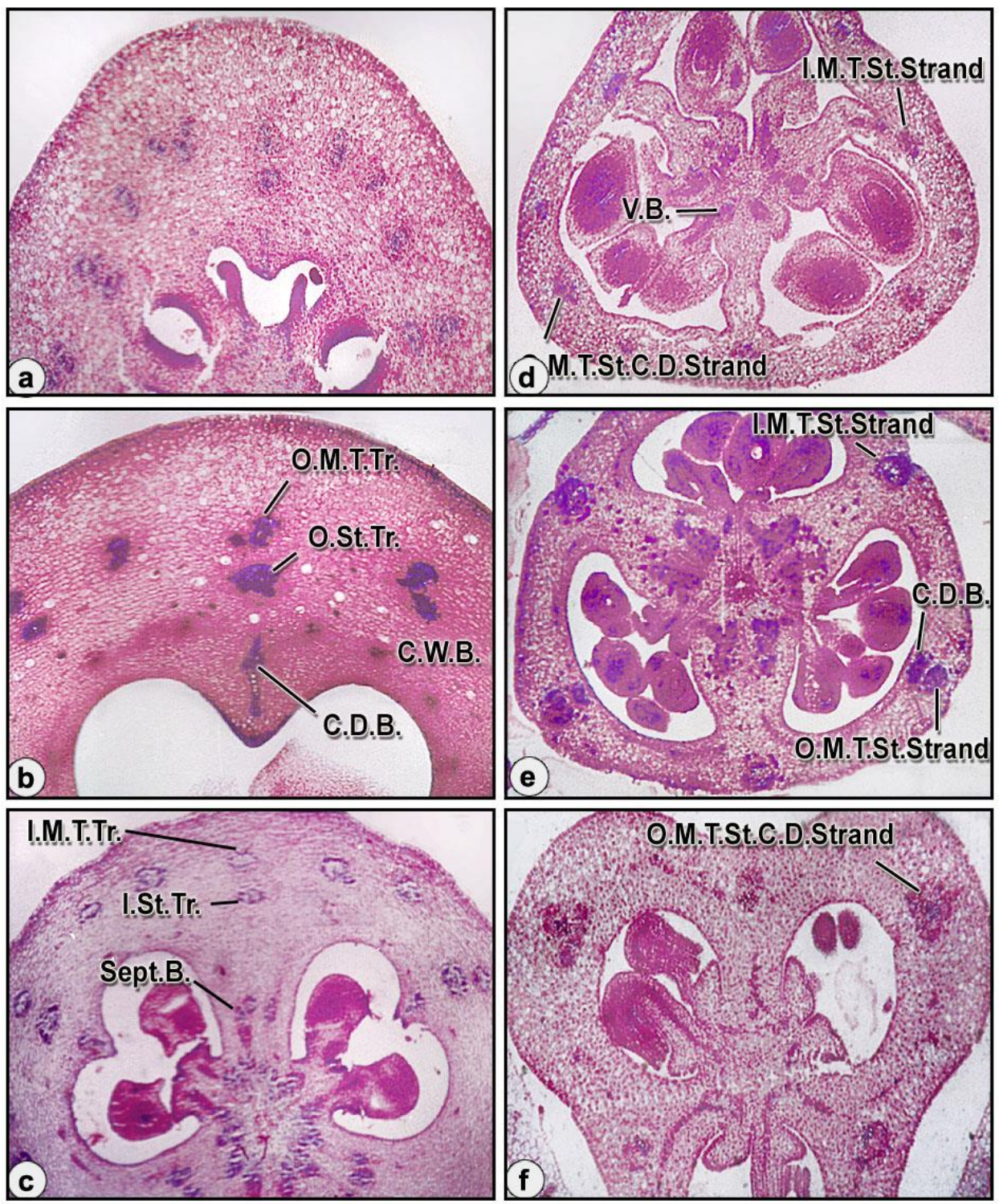

Figure 2. Variations in the casing vasculature in some of the taxa studied. a. Agave americana, b. Agave sisalana, c. Furcraea foetida, d. Narcissus tazetta, e. Gladiolus x gandavensis, f. Iris x germanica. Abbreviations: C.D.B.: Carpellary Dorsal Bundle; C.W.B.: Carpellary Wall Bundle; I.M.T.St.Strand: Inner Median Tepal Staminal Strand; I.M.T.Tr.: Inner Median Tepal Trace; I.St.Tr.: Inner Staminal Trace; O.M.T.St.C.D.Strand: Outer Median Tepal Staminal Carpellary Dorsal Strand; O.M.T.Tr.: Outer Median Tepal Trace; O.M.T.St.Strand: Outer Median Tepal Staminal Strand; O.St.Tr.: Outer Staminal Trace; Sept. B.: Septal Bundle. 

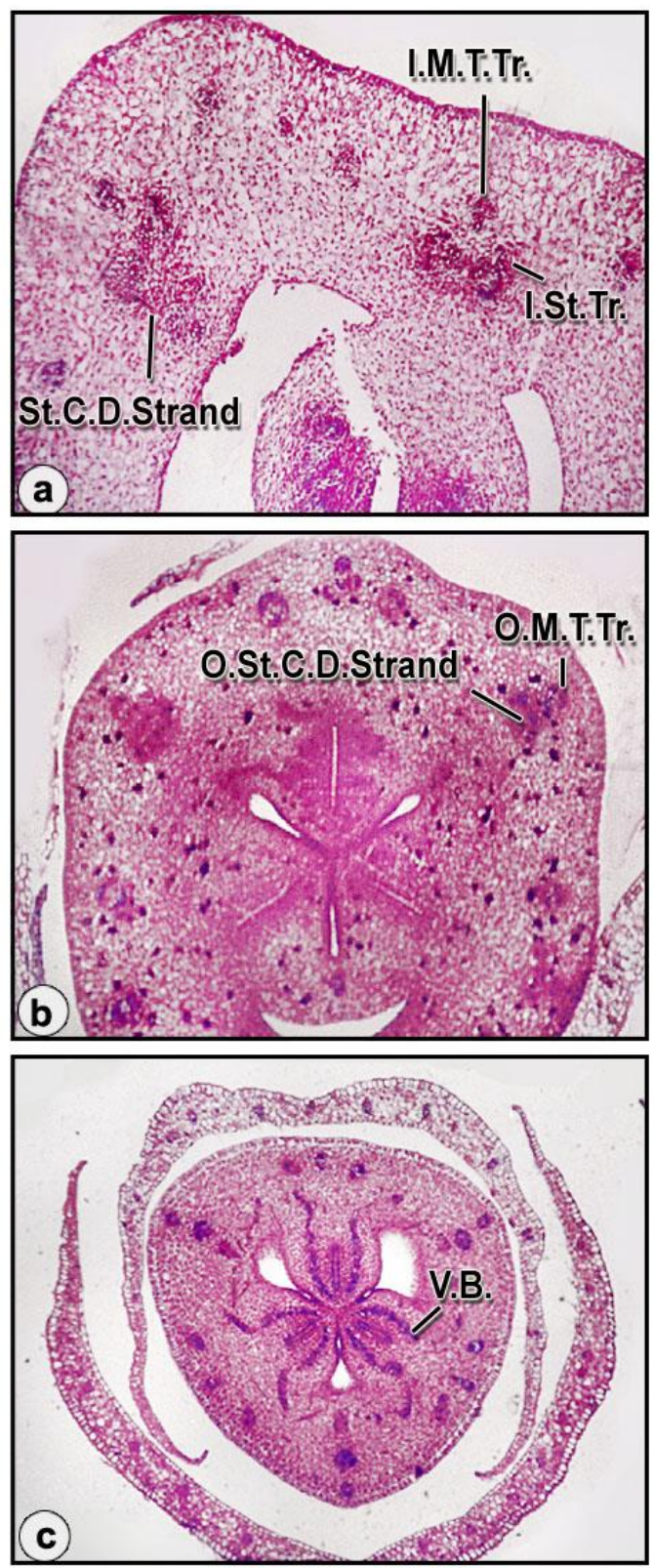

Figure 3. Variations in the vasculature at the top of the ovary in some of the taxa studied. a. Hymenocallis caribaea, b. Antholyza aethiopica, c. Freesia refracta.

Abbreviations: I.M.T.Tr.: Inner Median Tepal Trace; I.St.Tr.: Inner Staminal Trace; O.M.T.Tr.: Outer Median Tepal Trace; O.St.C.D.Strand: Outer Staminal Carpellary Dorsal Strand; St.C.D.Strand: Staminal Carpellary Dorsal Strand; V.B.: Ventral Bundle. 

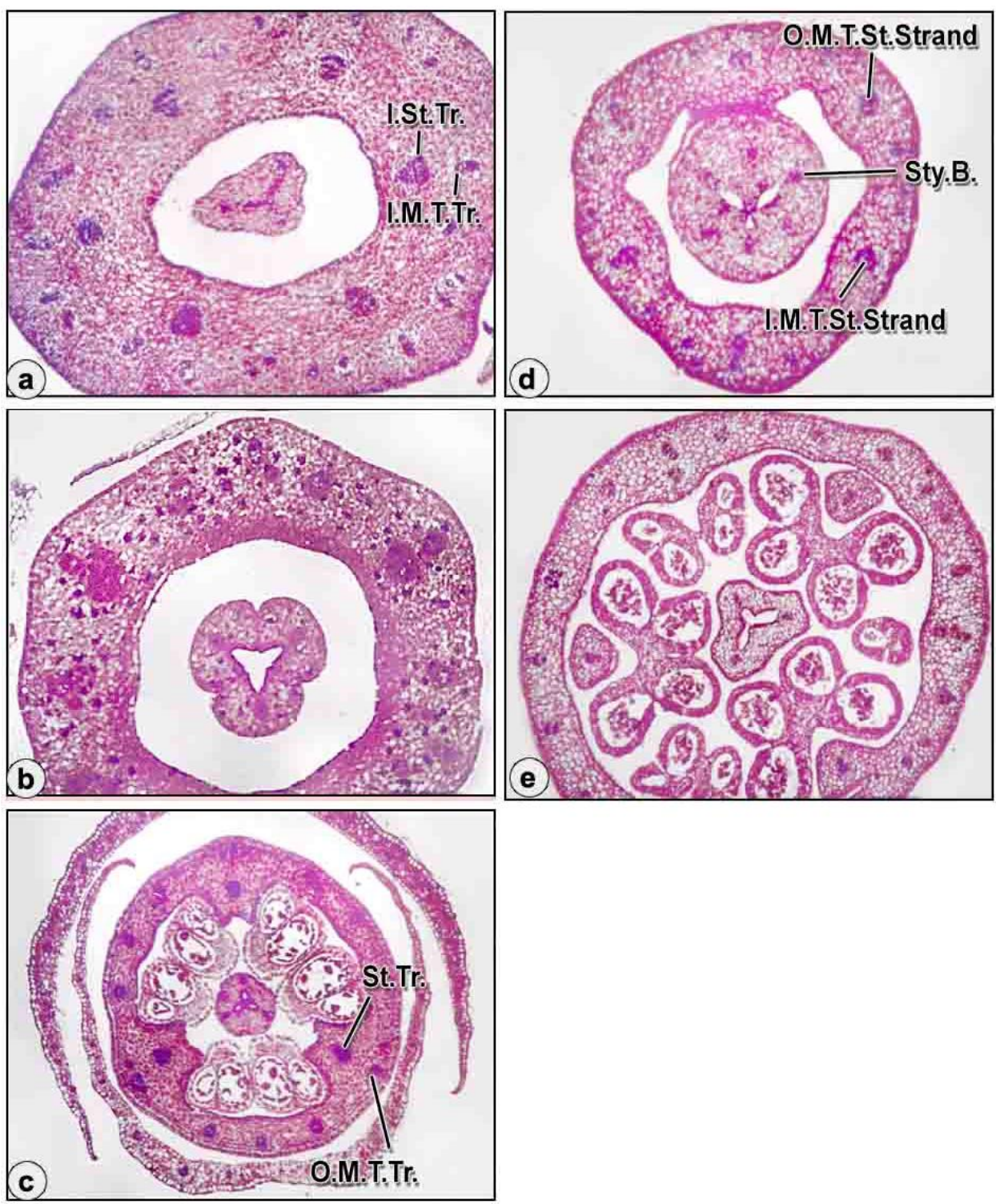

Figure 4. Variations in the collar vasculature in some of the taxa studied. a. Crinum bulbispermum, b. Antholyza aethiopica, c. Freesia refracta, d. \& e. Narcissus tazetta.

Abbreviations: I.M.T.Tr.: Inner Median Tepal Trace; I.M.T.St.Strand: Inner Median Tepal Staminal Strand; I.St.Tr.: Inner Staminal Trace; O.M.T.Tr.: Outer Median Tepal Trace; O.M.T.St.Strand: Outer Median Tepal Staminal Strand; St.Tr.: Staminal Trace; Sty.B.: Stylar Bundle. 

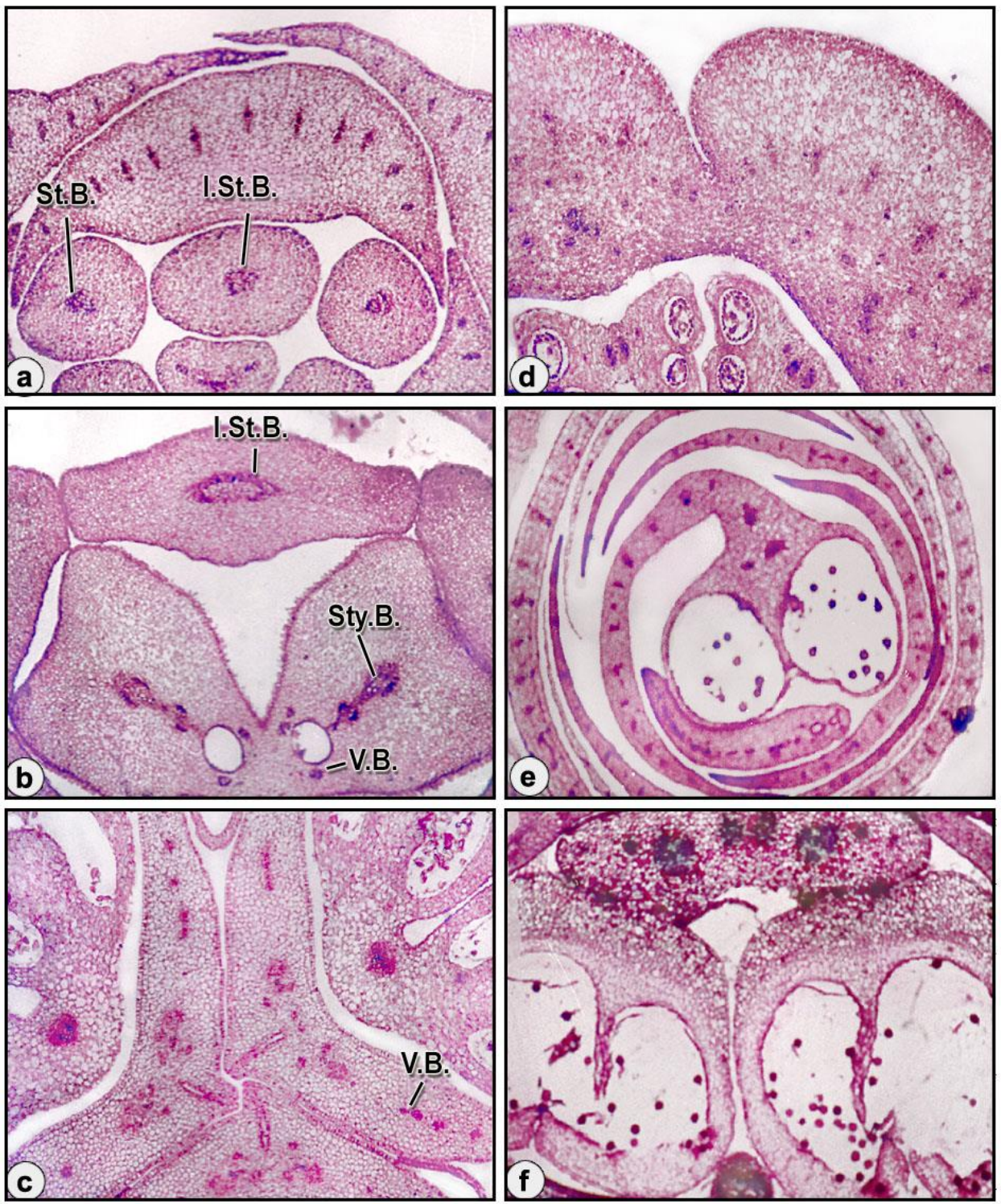

Figure 5. Variations in the stamens, style and stigma vasculature, in some of the taxa studied. a. Crinum $\mathrm{x}$ powellii, b. Furcraea foetida, c. Iris x germanica, d. Agave americana, e. Canna indica, f. Alpinia speciosa.

Abbreviations: I.St.B.: Inner Staminal Bundle; O.St.B.: Outer Staminal Bundle; Sty.B.: Stylar Bundle; V.B.: Ventral Bundle. 


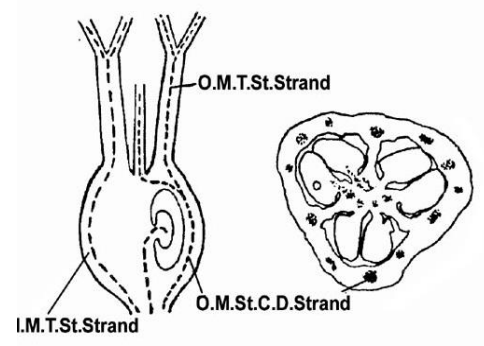

$\mathbf{a}$
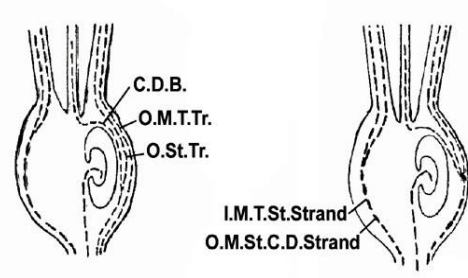

e

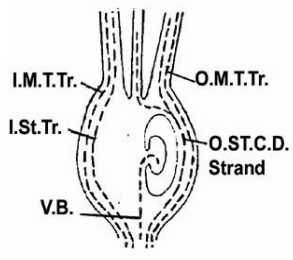

b

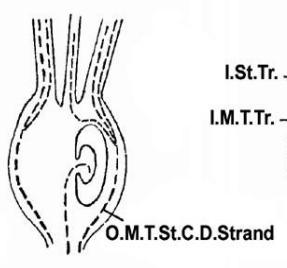

g

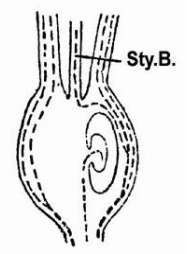

c

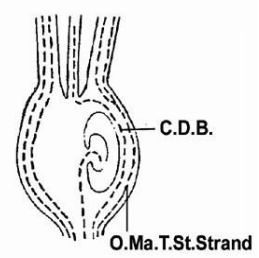

d

Figure 6. Longitudinal sections showing the significance of floral vascularization in the interpretation on the nature of epigynous flowers.

Abbreviations: C.D.B.: Carpellary Dorsal Bundle; I.M.T.Tr.: Inner Median Tepal Trace; I.M.T.St.Strand: Inner Median Tepal Staminal Strand; I.St.Tr.: Inner Staminal Trace; O.Ma.T.St.Strand: Outer Marginal Tepal Staminal Strand; O.M.T.St.Strand: Outer Median Tepal Staminal Strand; O.M.T.St.C.D.Strand: Outer Median Tepal Staminal Carpellary Dorsal Strand; O.M.T.Tr.: Outer Median Tepal Trace; O.St.C.D.Strand: Outer Staminal Carpellary Dorsal Strand; O.St.Tr.: Outer Staminal Trace; Sty.B. Stylar Bundle; V.B.: Ventral Bundle.

\section{Notes on contributor}

Sherif Mohamed SHARAWY - is a plant taxonomist/professor of plant taxonomy in Botany Department, Faculty of Science, Ain Shams University with a special interest in the biogeographic dynamics of the Mediterranean region. His work focuses in the taxonomic and systematic characterization of the Mediterranean region vascular flora, by using morphological, anatomical, molecular, karyological techniques. 


\section{References}

APGII. 2003. An update of the Angiosperm phylogeny Group classification for the orders and families of flowering plants: APGII. Bot. J. Linn. Soc. 141: 399-436.

BAILEY L. H. 1976. A concise dictionary of the plant cultivated in the United States and Canada. Staff of the L.H. Bailey Hortorium, Cornella University. MacMillan Pub. Co. INC. New York, 1290.

BASSO-ALVES J. P., GOLDENBERG R. \& TEIXEIRA S. P. 2017. The ontogenetic bases for variation in ovary position in Melastomataceae. Am. J. Bot. 104: 1142-1156.

BESSEY C. E. 1915. The phylogenetic taxonomy of flowering plants. Annals of the Missouri Botanical Garden. 2(1/2), Anniversary Proceedings: 109-164.

BLASER H. W. 1954. The morphology of the flower and inflorescence of Mitchella repens. Am. J. Bot. 41: 533539.

BLASER H. W. \& EINSET J. 1950. Flower structure in periclinal chimeras of apple. Am. J. Bot. 37: $297-304$.

BOULOS L. 2000. Flora of Egypt. Vol. 2. Al Hadara Publishing, Cairo, Egypt.

BOULOS L. 2009. Flora of Egypt Checklist. Revised Annotated Edition, Al Hadara Publishing, Cairo, Egypt.

BOUTINEAU E. 1883. De la fleur des Rosacees. Contribution a'l'etude des ovaries inferes. These de l'Ecole de Pharmacie de Paris.

CRONQUIST A. 1968. The evolution and classification of flowering plants. Thomas Nelson and Sons, Ltd., London.

DE CANDOLLE C. 1891. Recherches sur les inflorescences epiphylls. Mem. Soc. Phys. Hist. Nat. Geneve Suppl.

DOUGLAS G. E. 1944. The inferior ovary. Bot. Rev. 10: 125-186.

DOUGLAS G. E. 1957. The inferior ovary. Bot. Rev. 23: 1-46.

DOUGLAS S. E., FISHBEIN M. \& KUZOFF R. K. 2003. Evolution of Epigyny. International Journal of Plant Sciences. 164(S5): 251-264.

DOWDING E. 1931. Floral morphology of Arceuthobium americanum. Bot. Gaz. 91: 42-54.

DUCHARTRE P. 1841. Observation sur quelques parties de la fleur dans le Dipsacus sylvestris Mill., et dans l'Helanthus annus Linn. Ann. Sci. Nat. II. Bot. 16: 221-234.

DUCHARTRE P. 1842. Observation sur la fleur et plus particulierement sur l'ovarie de l'Oenothera suaveolens $\mathrm{H}$. P. Ann. Sci. Nat. II. Bot. 18: 339-356.

EAMES A. J. 1929. The role of floral anatomy in the determination of angiosperm phylogeny. Proc. Int. Cong. Plant Sci., 1926, I: 423-427.

EAMES A. J. 1931. The vascular anatomy of the flower with refutation of the theory of carpel polymorphism. Am. J. Bot. 18: 147-188.

EAMES A. J. 1953. Floral anatomy as an aid in generic limitation. Chron. Bot. 14: 126-132.

EAMES A. J. \& Mac DANIELS L. H. 1947. An introduction to plant anatomy. $2^{\text {nd }}$ ed. McGraw-Hill, New York. FAHN A. 1982. Plant Anatomy, $3^{\text {rd }}$ ed., Pergamon, Oxford.

GUSTALSSON M. H. G. \& ALBERT V. A. 1999. Inferior ovaries and angiosperm diversification. Mol. Syst. Plant Evol. 57: 403-431.

HENSLOW G. 1891. On the vascular system of floral organs and their importance in the interpretation of the morphology of flowers. Bot. J. Linn. Soc. 28: 151-197.

HUTCHINSON J. 1948. British Flowering Plants. Mac-Millan Co., London.

HUTCHINSON J. 1973. The Families of Flowering Plants, $3^{\text {rd }}$ ed. Oxford University Press, London.

HUXLEY A., GRIFFITHS M. \& LEVY M. 1992. Dictionary of Gardening, vol. 1-4, United Kingdom, Macmillan Press Limited.

JOHANSEN D. A. 1940. Plant Microtechnique. New York Book Company, 523 pp.

JUDSON J. E. 1929. The morphology and vascular anatomy of the pistillate flowers of the cucumber. Am. J. Bot. 16: 69-86.

KAPLAN D. R. 1967. Floral morphology, organogenesis and interpretation of the inferior ovary in Downingia bacigalupii. Am. J. Bot. 54: 1247-1290.

KHALIFA S. F., KAMEL W. M., GAZAR M. H. \& EL-BANHAWY A. H. 2009. Variabilities in the vascularization of the inferior ovary of certain dicotyledonous species. Assiut. Univ. J. Bot. 38(2): 41-79.

KIRKWOOD J. E. 1905. The comparative embryology of the Cucurbitaceae. Bull. N. Y. Bot. Gar. 3: 313-402.

KOEHNE E. 1869. Ueber Bluthenentwicklung bei den Compositen. Diss., Berlin.

KOZO POLJANSKI B. 1926. The morphology of the flower of Umbelliferae. Bull. Soc. Nat. Voroneje.

LESTIBOUDOIS T. 1855. Carpographie anatomique. Ann. Sci. Nat. IV. Bot. 3: 47-72.

OKIMOTO M. C. 1948. Anatomy and histology of the pineapple inflorescence and fruit. Bot. Gaz. 110: $217-231$.

PANDY B. P. 1982. Plant Anatomy. S. Chand and Co. Ltd. Ram Nagar, New Delhi. 
PAYER J. B. 1857. Traite d'organogenic compare de la fleur. Paris.

PURI V. 1951. The role of floral anatomy in the solution of morphological problems. Bot. Rev. 17: 471-553.

RASTOGI S. P. 1951. Vascular anatomy of the flower of certain species of the Myrtaceae. M.Sc. thesis, Agra Univ.

SAUNDERS E. R. 1925a. On carpel polymorphism. Ann. Bot. 39: 122 -168.

SAUNDERS E. R. 1925b. The Inferior Ovary. New Phyt. 24: 179-185.

SAUNDERS E. R. 1925c. Perigyny and carpel polymorphism in some Rosaceae. New Phyt. 24: 206-224. 78.

SHARMA D. N. 1949. Vascular anatomy of the flower of some species of the Cactaceae. Thesis, Agra Univ. India.

SMITH F. H. \& SMITH E. C. 1942. Anatomy of the inferior Ovary of Darbya. Am. J. Bot. 29(6): 464-471.

STACE C. A. 1985. Plant taxonomy and biosystematics. Edward Arnold, London.

STEBBINS G. L. 1977. Floral morphology. Memoris of the Indian Bot. Soc., Memoris 3: Recent advances in Angiosperm: 173-178.

SWAMY B. G. 1948. Vascular anatomy of the orchid flowers. Bot. Mus. Leaf. Harvard Univ. 13: 61-95.

TÄCKHOLM V. 1974. Students' Flora of Egypt, ed. 2, Cairo University, Egypt.

TAKHTAJAN A. 1969. Flowering Plants. Origin and dispersal. Translated by C. Jeffrey, Olivers and Boyd. Edinburgh. Venning F. D. 1945. Accessory vascular bundles in Murraya koenigi (L.), Spreng. (Rutaceae: Auranioideae). J. Wash. Acad. Sci. 35: 352-356.

TREVIRANUS L. C. 1859. Ueber Frucht - und Samen - bau der Mistel. Bot. Zeit. 17: 345-346.

TREVIRANUS L. C. 1861. Ueber Fruchtbau und einige Gattungen der Doldengewachse. Bot. Zeit. 19: 9-14.

VAN TIEGHEM P. 1870. Recherches sur la symetrie de structure des plantes vascularires. Ann. Sci. Nat. V. Bot. 12: 329-339.

VAN TIEGHEM M. P. 1871. Recherches sur la structure du pistil et sur l'anatomie compare de la fleur. Mem. Savants etrangers a l'Institut de France, Paris. 21: 1-261.

\section{How to cite this article:}

SHARAWY S. M. \& KHALIFA S. F. 2018. The nature of the inferior ovary in some monocotyledonous families. J. Plant Develop. 25: 25-42. https://doi.org/10.33628/jpd.2018.25.1.25 